\title{
TIDD PFBC Demonstration Project
}

\author{
Quarterly Report \\ January - March 1995
}

April 1995

Work Performed Under Contract No.: DE-FC21-87MC24132

\author{
For \\ U.S. Department of Energy \\ Office of Fossil Energy \\ Morgantown Energy Technology Center \\ Morgantown, West Virginia \\ By \\ American Electric Power Service Corporation \\ Columbus, Ohio
}

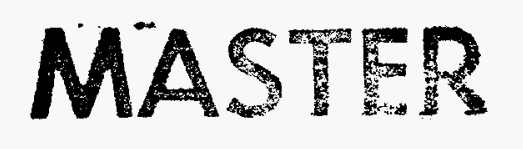




\section{DISCLAIMER}

This report was prepared as an account of work sponsored by an agency of the United States Government. Neither the United States Government nor any agency thereof, nor any of their employees, makes any warranty, express or implied, or assumes any legal liability or responsibility for the accuracy, completeness, or usefulness of any information, apparatus, product, or process disclosed, or represents that its use would not infringe privately owned rights. Reference herein to any specific commercial product, process, or service by trade name, trademark, manufacturer, or otherwise does not necessarily constitute or imply its endorsement, recommendation, or favoring by the United States Government or any agency thereof. The views and opinions of authors expressed herein do not necessarily state or reflect those of the United States Government or any agency thereof.

This report has been reproduced directly from the best available copy.

Available to DOE and DOE contractors from the Office of Scientific and Technical Information, 175 Oak Ridge Turnpike, Oak Ridge, TN 37831; prices available at (615) 576-8401.

Available to the public from the National Technical Information Service, U.S. Department of Commerce, 5285 Port Royal Road, Springfield, VA 22161; phone orders accepted at (703) 487-4650. 


\section{DISCLAIMER}

Portions of this document may be illegible in electronic image products. Images are produced from the best available original document. 


\title{
TIDD PFBC Demonstration Project
}

\author{
Quarterly Report \\ January - March 1995
}

Work Performed Under Contract No.: DE-FC21-87MC24132

\author{
For \\ U.S. Department of Energy \\ Office of Fossil Energy \\ Morgantown Energy Technology Center \\ P.O. Box 880 \\ Morgantown, West Virginia 26507-0880 \\ By \\ American Electric Power Service Corporation \\ 1 Riverside Plaza \\ Columbus, Ohio 43215
}

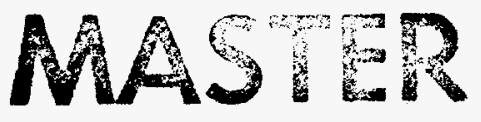


GLOSSARY OF ACRONYMS AND ABBREVIATIONS USED IN THIS REPORT

I. INTRODUCTION AND SUMMARY

II. DESIGN AND PERMITTING

A. Engineering and Design Division 1

B. Environmental Engineering Division 2

C. Performance Testing 2

$\begin{array}{ll}\text { III. } & \text { PROJECT SUPPORT }\end{array}$

$\begin{array}{ll}\text { IV. TIDD PFBC PLANT OPERATIONS } & 11\end{array}$

A. Operations 11

$\begin{array}{ll}\text { B. Maintenance } & 16\end{array}$

$\begin{array}{lll}\text { V. MANPOWER REPORT } & 18\end{array}$

$\begin{array}{lr}\text { V. COST DATA } & 19\end{array}$ 


\section{GLOSSARY OF ACRONYMS AND ABBREVIATIONS USED IN THIS REPORT}

AARP

$A B$

AEP

AEPSC

AFC

AFL

ABBC

AOP

B\&W

BWCC

BOP

CBI

CSWD

CTF

DOE

DRC

E\&SC

ECP

EMP

EOP

EPA

ESP

FAT
Annunciator Alarm Response Procedures

ASEA Babcock - A business partnership between a subsidiary of ABBC and the Babcock \& Wilcox Company (USA)

American Electric Power Company, Inc.

American Electric Power Service Corporation, a subsidiary of AEP

Approved for Construction

Approved for Layout

ABB Carbon - a subsidiary of ASEA-Brown Boveri (subcontractor)

Abnormal Operating Procedure

The Babcock \& Wilcox Company (subcontractor)

The Babcock \& Wilcox Construction Company (subcontractor)

Balance of Plant

Chicago Bridge and Iron, Inc. (subcontractor)

Cable Schematics Wiring Drawings

Component Test Facility

Department of Energy (United States)

Design Review Committee

Electrical Equipment Service Corporation (subcontractor)

Engineering Control Procedure

Environmental Monitoring Plan

Emergency Operating Procedure

Environmental Protection Agency

Electrostatic Precipitator

Net 90 - Factory Acceptance Test 


\section{GLOSSARY OF ACRONYMS AND ABBREVIATIONS USED IN THIS REPORT}

GSU

GT

HPT

HVAC

$18 \mathrm{C}$

IOI

LPT

MCR

MCS

MCC

MED

NDE

NEMA

NOP

NOVAA

NPDES

OEPA

OCDO

OPCo

PES

PFBC

PMP

POPS
Generator Step-up Transformer

Gas Turbine

High Pressure Tubine

Heating, Ventilating \& Air Conditioning

Instrumentation \& Control

Initial Operating Instructions

Low Pressure Turbine

Material Control Record

Management Command System

Motor Control Center

Mechanical Engineering Division

Nondestructive Examination

National Electric Manufacturers Association

Normal Operating Procedure

North Ohio Valley Air Authority

National Pollutant Discharge Elimination System

Ohio Environmental Protection Agency

Ohio Coal Development Office - a part of Ohio Department of Development

Ohio Power Company

Plant Electrical Systems

Pressurized Fluidized Bed Combustion

Project Management Plan

Plant Operations and Performance System 


\section{GLOSSARY OF ACRONYMS AND ABBREVIATIONS USED IN THIS REPORT}

ppb

Parts Per Billion

PT

Permit to Install

PTO Permit to Operate

PWHT Post Weld Heat Treatment

RDR Request for Drawing Revision

RFQ Request for Quotation

SD-O System Description (Rev. 0)

SD-1 System Description (Rev. 1)

SD-2 System Description (Rev. 2)

SD-2.5 System Description (Rev. 2.5)

SD-3.0 System Description (Final)

SPCC Spill Prevention Control \& Countermeasures 
This is the thirty-second Technical Progress Report submitted to the Department of Energy in connection with the Cooperative Agreement between the DOE and the Ohio Power Company for the Tidd PFBC Demonstration Plant. This report covers the period from January 1, 1995 to March 31, 1995.

Major activities during this period include:

- The unit operated for 718 hours on coal, bringing the grand total for coal fire through the end of the quarter to 11,442 hours.

- There were seven gas turbine starts, nine bed preheater starts, and nine operating periods on coal.

- During this quarter, total gross generation was $57,693 \mathrm{MWH}$, the peak unit output for one hour was $74 \mathrm{MWH}$, and the coal consumption was 27,866 tons.

- Twelve performance tests were conducted during this quarter, bringing the total number of tests for the plant to 95 .

- On March 30,1995, at 8:27 am, the Tidd PFBC Demonstration Plant was manually tripped for the last time.

Major activities planned for the next period include:

- Inspection of the equipment.

- Submittal of the final report on the first three years of operation.

- Continue development of the decommissioning plan for the Plant.

II. DESIGN AND PERMITTING

\section{A. Engineering and Design}

\section{Sorbent Preparation System}

During the week of March 20 , the sorbent preparation system sizer was reconfigured to a double screening arrangement in order to produce a product with a minimal quantity of minus 60 mesh fines. Dramatic improvements in sorbent utilization had been achieved in the preceding year by using a sorbent with reduced fines. However, that material was crushed and sized at the quarry and delivered by bulk trucks. This product, termed "Designer" dolomite, was nominally $100 \%$ minus 12 mesh with approximately $25 \%$ less than 60 mesh in size. It was made with the typical Plum Run Greenfield dolomite that had become the standard sorbent used at Tidd. Reconfiguration of the sizer was performed in an attempt to produce this "Designer" sorbent on site.

Tidd PFBC Demonstration Project

DOE Instrument DE-FC21-87 MC24132.000
Technical Progress Report

First Quarter CY 1995 
In the spring of 1994, the original sizer was replaced with a larger double deck screen. This new sizer was typically run throughout 1994 with its upper and lower decks arranged in parallel using 12 mesh self-cleaning screens in both decks. In this configuration, the oversize product from both decks was recycled to the system crusher, and the material passing through the screens was the prepared product. The product produced was nominally $100 \%$ minus 12 mesh with approximately $45 \%$ minus 60 mesh.

In order to produce the "Designer" material on site, the sizer was reconfigured in a series arrangement with a 12 mesh screen in the top deck and a 50 mesh screen in the bottom. The oversize product from the 12 mesh deck was recycled to the crusher, whereas the material passing through the 50 mesh screen was collected by vacuum truck and discarded as waste. The material collected between the screens became the prepared product. This type of operation was termed "scalping/ dedusting" mode. Due to the rejection of the fines and the series arrangement of the screen decks, the capacity of system was reduced to approximately 4 - 5 tons/ hour. This low capacity limited the load at which the unit could be tested with this product. Test 94 was conducted on March 23, 1995 at a bed level of 90 inches using this site prepared "designer" Plum Run Greenfield dolomite.

\section{Gas Turbine}

The HGCU insulation failure in February caused some damage to the HPT blading. Four $2^{\prime \prime} \times 2^{\prime \prime}$ metal washers used to retain insulation had broken free, allowing insulation and washers to go downstream to the gas turbine. Gas turbine vibration and HPT disk temperatures went high following the incident. Upon inspection, three of the washers were found lodged in the HPT inlet guide vanes. The fourth washer went through the gas turbine and was found in pieces in the outlet duct. A boroscope inspection of the HPT showed impact damage to the first stage rotating blades trailing edges. Three of those blades had material removed by the impact. The downstream stages had additional impacts of lesser severity than the first stage. After evaluation of the visible impact damage and comparison to acceptable industry standards, a decision was made to continue to operate the gas turbine without additional internal inspection. The gas turbine ran for the balance of the quarter with slightly higher vibration and was tripped from service for the final time on $3 / 31$ without incident.

B. Environmental

All monthly and quarterly environmental monitoring reports were filed with the North Ohio Valley Air Authority and Ohio EPA, as required.

The DOE's Environmental Monitoring Plan (EMP) requires quarterly reports be filed within 60 days of the end of each quarter. In compliance with that requirement, the EMP quarterly report for the fourth quarter of 1994 was submitted to DOE.

Monitoring of solid, liquid, and gaseous waste streams as required by the operations phase of the EMP was performed throughout the quarter.

\section{Performance Testing}

Twelve performance tests were conducted during the final three months of the Tidd test program bringing the total number of tests completed during the project to 95 . The various

Tidd PFBC Demonstration Project

DOE Instrument DE-FC21-87 MC24132.000
Technical Progress Report

First Quarter CY 1995 
coals tested during the quarter included MM Pittsburgh \#8 coal, Minnehaha coal, and Consol Mahoning Valley Pittsburgh \#8 coal; and the sorbents tested included Plum Run Greenfield dolomite, Mulzer dolomite, and National Lime Delaware limestone. Preliminary results for Tests 84 through 95 completed during the quarter are presented in the attachment "Test Results Summary". Graphical results for tests completed in the fourth year of operation are presented in Figures 1 through 5. A description of the most significant tests completed during the quarter is presented below.

On 2/ 22/95 Test 85 was completed using MM Pittsburgh \#8 coal and Plum Run Greenfield \#12-mesh "designer" dolomite at 132" bed level and 1582F bed temperature. The unit grossed an average of 72.1 MW over the four hour test period which was the highest output ever achieved during a performance test. Firing rate was $218 \mathrm{MW}_{\mathrm{t}}$ (approximately $5 \%$ over design) and feedwater flow was $468 \mathrm{kpph}$. A Ca/ S ratio (adjusted to $90 \%$ SR and $1580 \mathrm{~F}$ bed temperature) of 1.44 was achieved. Although sorbent utilization was better than with site prepared sorbent, the $\mathrm{Ca} / \mathrm{S}$ ratio was not as good as expected for the "designer" sorbent being tested. One reason for the higher than expected $\mathrm{Ca} / \mathrm{S}$ ratio may have been due to the relatively short time in allowing the bed to mature prior to conducting the test. Normally the bed is allowed 36 hours to mature after switching sorbents, however, due to delivery constraints and a limited window of cold weather opportunity to test the unit at full load, the sorbent hit the bed only 18 hours prior to the beginning of the test period.

On 2/27/95 Test 87 was completed using MM Pittsburgh \#8 coal and Mulzer \#12-mesh site prepared dolomite at $116^{\prime \prime}$ bed level. A Ca/ S ratio (adjusted to $90 \%$ SR and 1580F bed temperature) of 1.75 was achieved. This is within the range of results obtained with Plum Run Greenfield \#12-mesh site prepared dolomite at the same bed level indicating that the two dolomites have similar reactivities.

On $2 / 28$ and $3 / 2 / 95$ Tests 88 and 89 were completed using Minnehaha coal which has approximately half the sulfur content of MM Pittsburgh \#8 coal. Mulzer dolomite was used for Test 88 and PRG dolomite for Test 89 . The tests were conducted at 114" and 125" bed levels respectively. The $\mathrm{Ca} / \mathrm{S}$ ratios calculated for these tests are approximately $30 \%$ higher than with the MM Pittsburgh \#8 coal. The decline in sorbent utilization may be due in part to the lower sulfur content of Minnehaha coal. It should also be mentioned that a much higher content of water was required to produce an acceptable coal water paste. The Minnehaha coal required $35 \%$ to $40 \%$ water content in the paste where typically $25 \%$ to $28 \%$ water content is used.

On 3/3/95 coal was switched to Consol Mahoning Valley Pittsburgh \#8 coal for the remainder of the test program. Tests 90 through 93 were conducted in March 1995 using Plum Run Greenfield \#12-mesh site prepared dolomite at various bed levels in order to develop a new baseline curve with the Consol coal. Although the sulfur content of the Consol coal is approximately $30 \%$ lower than that of the MM coal, the Ca/ S ratios obtained during the Consol coal tests are closely in line with those of the MM Pittsburgh \#8 coal tests. Test 90 was conducted at full bed level (141 inches) and 1562F bed temperature; a $\mathrm{Ca}$ S ratio (adjusted to $90 \%$ SR and $1580 \mathrm{~F}$ bed temperature) of 1.62 was achieved.

Tidd PFBC Demonstration Project DOE Instrument DE-FC21-87 MC24132.000
Technical Progress Report

First Quarter CY 1995 
On 3/23/95 Test 94 was completed using Consol coal and Plum Run Greenfield dolomite while the sorbent preparation system was operating in the scalping/ dedusting mode. In this mode of operation the sorbent fines (less than 60-mesh) are separated from the process and discarded. The sorbent being tested is essentially $12 \times 60$ mesh. Due to the reduced capacity of the sorbent preparation system in this mode, the test was conducted at 90 inch bed level. A Ca/ S ratio (adjusted to $90 \%$ SR and 1580F bed temperature) of 1.54 was achieved during this test which is an improvement of approximately $20 \%$ better than the results obtained with the \#12-mesh site prepared dolomite at the same bed level. These results, when normalized to an equivalent bed level, represent sorbent utilization performance levels within the range of the earlier tests with PRG \#12-mesh "designer" dolomite and MM Pittsburgh \#8 coal. This test supports the theory that the optimum sorbent size consists of those particles just over the directly elutriable size of 60-mesh. Although analyses of the cyclone and bed ash samples have not yet been received for this test, it is expected that sulfation rates will be similar to those of the PRG \#12-mesh "designer" dolomite tests (i.e., bed ash sulfation rates of approximately $70 \%$ and cyclone ash sulfation rates of approximately $40 \%$ ). The cyclone ash/bedash split for this test was $63 \% / 37 \%$ compared to a typical ash split of $75 / 25$ for the \#12-mesh site prepared sorbent and 55/ 45 for the \#12-mesh "designer" sorbent.

The final test of the program was completed on $3 / 28 / 95$ while operating with Consol coal and National Lime Delaware \#12-mesh site prepared limestone (the Consol coal has similar ash fusion characteristics as the MM Pittsburgh \#8 coal). This test was conducted at 118" bed level and a reduced bed temperature of 1500F. The unit was operated for approximately 40 hours on limestone during which time the bed showed signs of deterioration (bed and evaporator temperature distributions were slowly degrading as bed density and steam flow continued to drop), however, there were no signs of excessive egg sinter formation in the bed drains. At the conclusion of the test, sorbent was switched back to PRG dolomite in order to stabilize bed conditions. The operating experiences gained from this test are similar to the experiences gained from the limestone testing of October 1994 when the unit was operated on Bucyrus \#18-mesh "designer" limestone for approximately 36 hours during which time bed conditions were similarly noted to be deteriorating again without the signs of excessive egg sinter formation. The difference in the latest two limestone tests from the earlier attempts of 1992-1993 (which resulted in unit shutdowns due to bed deterioration) is that the more recent tests used a finer size grade of limestone. The fact that excessive egg sinters were not observed during these latest two tests would lead us to believe that the limestone some how causes bed conditions to deteriorate which leads to conditions favorable for sinter formation as opposed to our previous belief that limestone operation causes egg sinter formation which leads to bed deterioration. Although testing at the Tidd Plant has not provided a clear understanding of the phenomenon that is taking place in the bed while operating with limestone, it does appear that fluidization of the bed is adversely affected by the presence of limestone. Additional investigation of how limestone impacts the bed is recommended.

Tidd PFBC Demonstration Project

DOE Instrument DE-FC21-87 MC24132.000
Technical Progress Report

First Quarter CY 1995 


\section{PROJECT SUPPORT}

\section{A. Schedule}

A preliminary schedule was developed covering disposition of the plant following termination of the Demonstration Program. The main tasks identified include Decommissioning of Operations, Decommissioning of the PFBC Support Facilities and development of a Site Utilization Plan. Support in the implementation of these tasks is being provided by the Plant, Environmental Engineering and the Labor Contracting Groups.

\section{B. Work in Progress}

\section{Current Activities Include:}

-Decommissioning and inspection of various systems

-Preparation and distribution of equipment inventory lists

-Preparation and proposal to the DOE for disposal of PFBC

equipment on site

-Submittal of data to the Ohio EPA pertinent to closure of the coal/ dolomite storage yard.

-Solicitation of budget estimates for asbestos abatement.

-Development of bid package for regrading the coal/ dolomite yard

-Preparation of accounting procedures for asset recovery. 
Table 1. Preliminary Test Results

TEST RESULTS SUMMARY

\begin{tabular}{|c|c|c|c|c|c|c|c|c|}
\hline & TEST NUMBER & & 84 & 85 & 86 & 87 & 88 & 89 \\
\hline & TEST DATE & & $02 / 01 / 95$ & $02 / 22 / 95$ & $02 / 24 / 95$ & $02 / 27 / 95$ & $02 / 28 / 95$ & $03 / 02 / 95$ \\
\hline & TEST PERIOD & & $2200-0155$ & $0200-0600$ & $2300-0600$ & $0200-0800$ & $0000-0800$ & $0600-1400$ \\
\hline \multicolumn{9}{|c|}{ COAL AND SORBENT TYPES } \\
\hline & COAL TYPE & & MM Pitts 8 & MM Pitts 8 & MM Pitts 8 & MM Pitts 8 & Minnehaha & Minnehaha \\
\hline & SORBENT TYPE & & PRG & PRG & PRG & Mulzer & Mulzer & PRG \\
\hline & sorbent mesh size - "site" or " & designer" & $\# 12$ site & \#12 design & \#12 site & \#12 site & $\# 12$ site & \#12 site \\
\hline \multicolumn{9}{|c|}{\begin{tabular}{|l|l} 
OPERATING DATA & \\
\end{tabular}} \\
\hline$n / a$ & BED LEVEL (CALC) & INCHES & 128.2 & 132.3 & 134.1 & 116.0 & 114.0 & 124.5 \\
\hline 886 & ST GEN MW & MW & 51.7 & 57.1 & 54.5 & 48.8 & 47.6 & 50.6 \\
\hline 885 & GT GENMW & MW & 14.0 & 15.0 & 15.2 & 11.9 & 12.0 & 15.0 \\
\hline$n / a$ & COAL PASTE FLOW (CALC & PPH & 73950 & 78866 & 78030 & 69920 & 88477 & 83311 \\
\hline 217 & MEAN BED TEMP & $\mathbf{F}$ & 1579.0 & 1582.3 & 1577.4 & 1581.7 & 1580.8 & 1577.6 \\
\hline 691,692 & INT VALVE INLET TEMP & $\bar{F}$ & 1516.8 & 1542.4 & 1552.4 & 1448.9 & 1436.0 & 1505.2 \\
\hline 191 & AVG. BED OUTLET O2 & PERCENT & 3.3 & 2.6 & 2.9 & 3.5 & 3.4 & 3.4 \\
\hline 260 & MEAN CYCLONE TEMP IN. & $\mathbf{F}$ & 1540.9 & 1566.9 & 1577.2 & 1471.3 & 1456.6 & 1525.7 \\
\hline 604 & AIR FLOW (INDICATED) & KPPH & 724.3 & 735.0 & 734.8 & 680.1 & 669.4 & 729.9 \\
\hline 864 & FEEDWATER FLOW (MVS) & KPPH & 432.7 & 468.1 & 452.4 & 412.0 & 398.3 & 425.9 \\
\hline \multicolumn{9}{|c|}{ EMISSIONS } \\
\hline 710 & SO2 LVG ESP (RAW) & PPM & 198.2 & 195.4 & 166.4 & 209.5 & 119.9 & 47.8 \\
\hline 709 & NOX LVG ESP (RAW) & $\overline{\mathrm{PPM}}$ & 111.0 & 98.4 & 109.5 & 119.1 & 127.6 & 158.9 \\
\hline$n / a$ & NOXLVGESP (CALC) & LB/MMBTU & 0.17 & 0.15 & 0.17 & 0.19 & 0.21 & 0.26 \\
\hline$n / a$ & SO2 LVG ESP (CALC) & LB/MMBTU & 0.48 & 0.46 & 0.40 & 0.51 & 0.31 & 0.12 \\
\hline \multicolumn{9}{|c|}{ FEEDSTOCK ANALYSIS } \\
\hline & COAL SULFUR (D/B) & WT. PCT. & 2.85 & 3.16 & 3.11 & 3.10 & 1.60 & 1.63 \\
\hline & COAL SO2 & LB/MMBTU & 4.48 & 4.88 & 4.85 & 4.94 & 2.49 & 2.53 \\
\hline & PASTE MOISTURE (A/F) & WT. PCT. & 26.46 & 27.19 & 27.40 & 26.40 & 40.97 & 34.28 \\
\hline & SORBENT CaO (D/B) & WT. PCT. & 29.81 & 29.39 & 29.98 & 28.68 & 28.97 & 29.14 \\
\hline & SORBENT SMD (from ELH) & MICRONS & 245 & 423 & 274 & 273 & 272 & 260 \\
\hline \multicolumn{9}{|c|}{ CALCULATED RESULTS } \\
\hline & FIRING RATE & MWT & 203.1 & 218.1 & 213.3 & 189.5 & 196.8 & 207.3 \\
\hline & SULFUR CAPTURE & PERCENT & 89.2 & 90.7 & 91.8 & 89.6 & 87.5 & 95.2 \\
\hline & $\mathrm{Ca} / \mathrm{S}$ TEST & RATIO & 1.71 & 1.48 & 1.84 & 1.71 & 2.01 & 3.08 \\
\hline & $\mathrm{Ca} / \mathrm{S} @ 90 \%, 1580$ TBED & RATIO & 1.77 & 1.44 & 1.68 & 1.75 & 2.23 & 2.33 \\
\hline & Ca/S@ 95\%, 1580 TBED & RATIO & 2.30 & 1.88 & 2.19 & 2.28 & 2.90 & $3 . \overline{3}$ \\
\hline & COAl EIOW & PDH & 51200 & 57102 & $50 a 50$ & $510^{01}$ & 57020 & 50750 \\
\hline & TOTAL SORBENT FLOW & $\mathrm{PPH}$ & $\frac{54385}{15560}$ & $\frac{5 / 422}{15960}$ & $\frac{56050}{18890}$ & $\begin{array}{l}5 / 461 \\
16680\end{array}$ & $\begin{array}{l}5<2 \angle 8 \\
10140\end{array}$ & $\frac{54152}{16510}$ \\
\hline & SORBENT IN PASTE & PERCENT & 0.0 & 0.0 & 0.0 & 0.0 & 0.0 & 0.0 \\
\hline & & & & & & & & \\
\hline & BED ASH FLOW & PPH & 6500 & 9390 & 7000 & 7860 & 3858 & 5947 \\
\hline & CYCLONE ASH FLOW & PPH & 14611 & 11666 & 16753 & 14771 & 11011 & 15063 \\
\hline & PERCENT CYCLONE ASH & PERCENT & 69.2 & 55.4 & 70.5 & 65.3 & 74.1 & 71.7 \\
\hline & HEAT BALANCE CLOSURE & PERCENT & 99.3 & 99.2 & 99.4 & 99.2 & 101.5 & 100.2 \\
\hline & CALCIUM CLOSURE & PERCENT & later & later & 96.1 & 86.1 & later & later \\
\hline & SULFUR CLOSURE & PERCENT & later & later & 98.7 & 96.3 & later & later \\
\hline & CYC ASH SULPHATION & PERCENT & later & later & 42.8 & 36.9 & later & later \\
\hline & BED ASH SULPHATION & PERCENT & later & 69.6 & 58.4 & 59.6 & later & later \\
\hline
\end{tabular}

Tidd PFBC Demonstration Project DOE Instrument DE-FC21-87 MC24132.000
Technical Progress Report First Quarter CY 1995 
Table 1. Preliminary Test Results (cont.)

TEST RESULTS SUMMARY

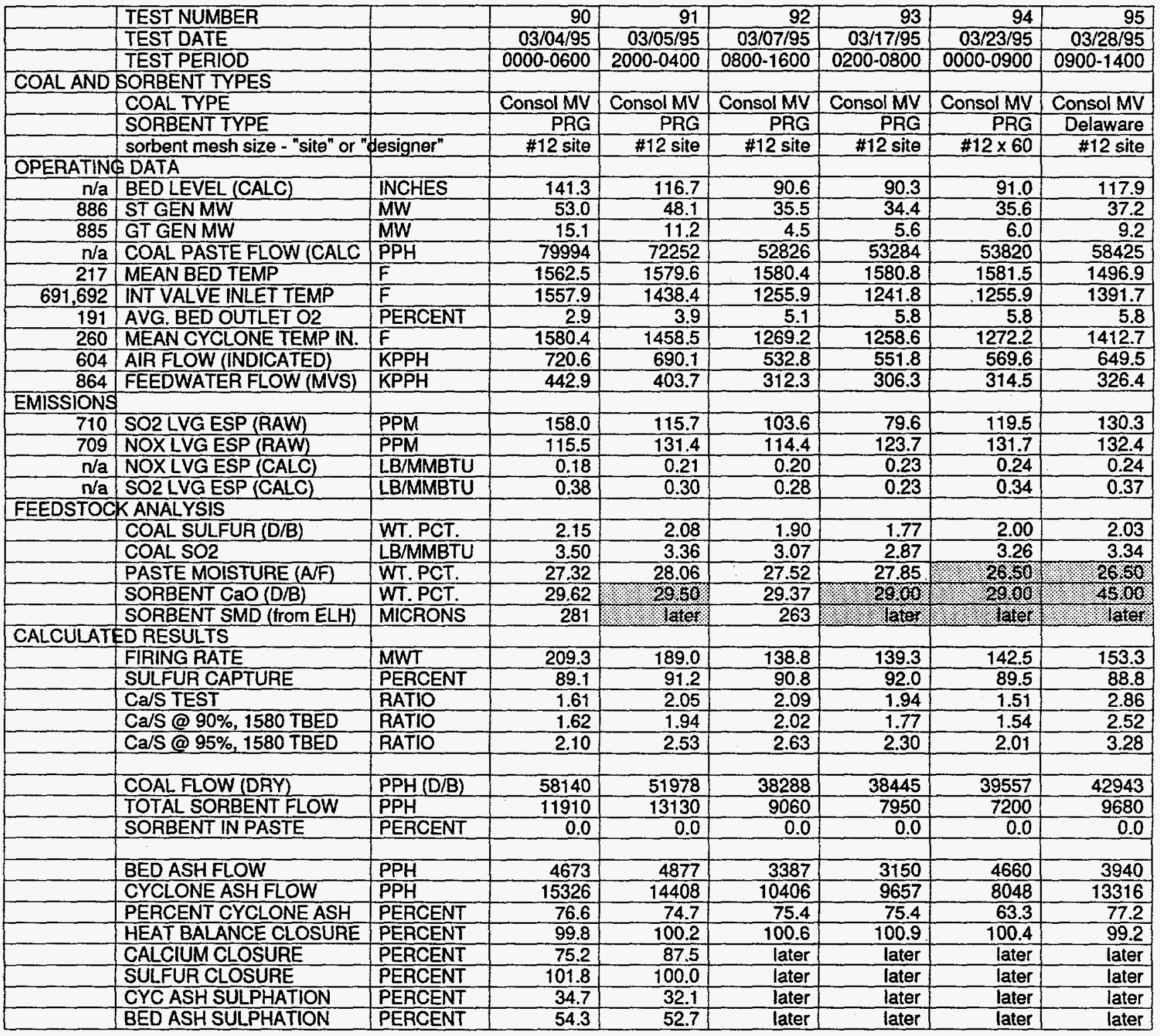

Tidd PFBC Demonstration Project DOE Instrument DE-FC21-87 MC24132.000
Technical Progress Report

First Quarter CY 1995 
Figure 1. Cal S Ratio vs. Bed Height at $90 \%$ S. R., 1580 F Bed Temp.

Tidd PFBC Demonstration Plant

$\mathrm{Ca} / \mathrm{S}$ Ratio vs. Bed Height at $90 \%$ SR, $1580 \mathrm{~F}$ Bed Temperature MM Pitts \#8 Coal with Plum Run, National Lime, or Mulzer Dolomite

Tests 48-77, 79-87

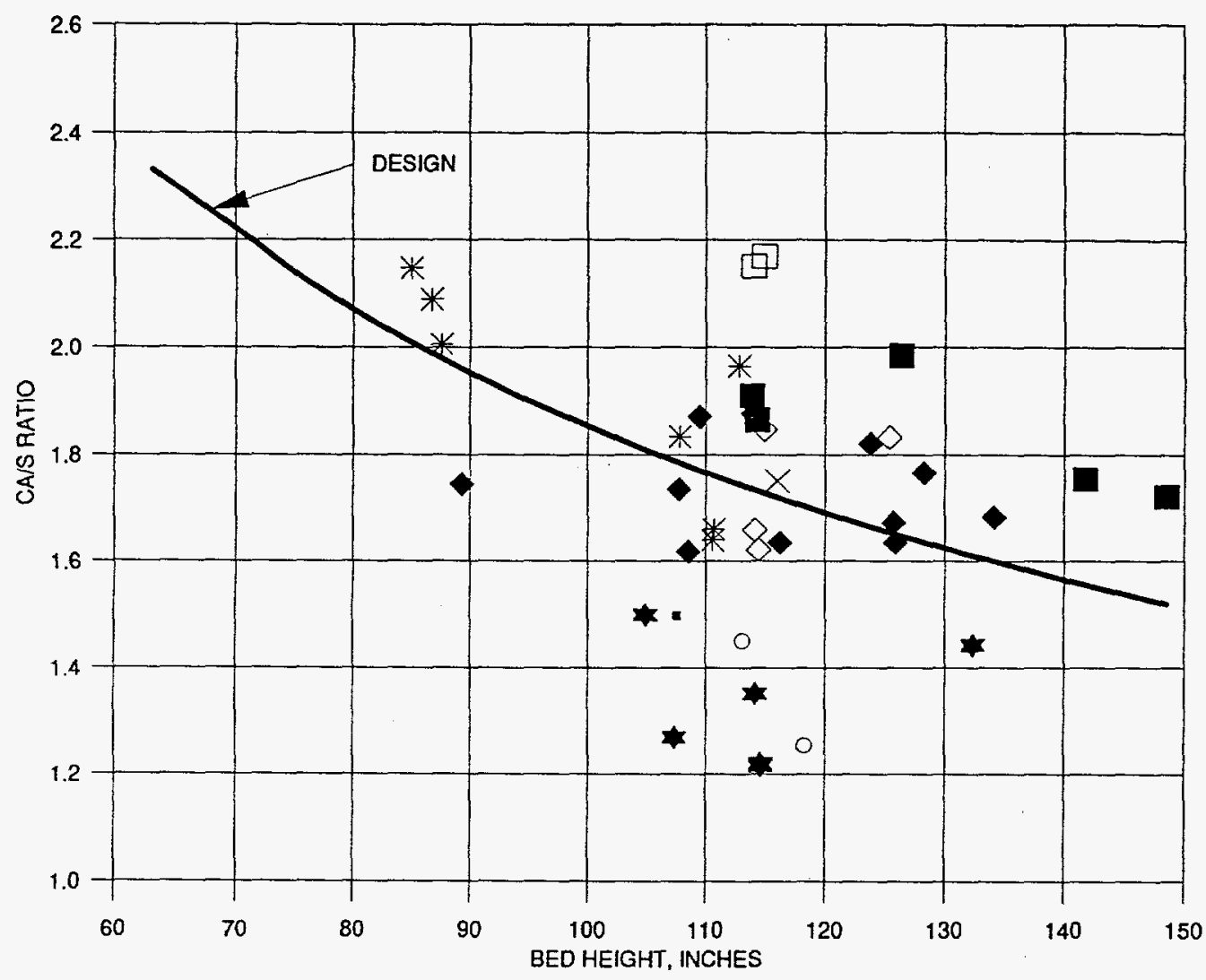

\begin{tabular}{|ccccc|}
\hline NLC \#6-mesh & NLC \#12-mesh & NLC \#20-mesh & PRG \#6-mesh & PRG \#10-mesh \\
Site Prepared & Designer & Designer & Site Prepared & Site Prepared \\
$\square$ & 0 & 0 & & $*$ \\
PRG \#12-mesh & PRG \#12-mesh & PRG/P \#20-mesh & Mulzer \#12-mesh & \\
Site Prepared & Designer & Designer & Site Prepared & \\
& & - & $X$ & \\
\hline
\end{tabular}

4yr-MM Pitts 8 7-APR-95

Tidd PFBC Demonstration Project DOE Instrument DE-FC21-87 MC24132.000
Technical Progress Report

First Quarter CY 1995 
Figure 2. Cal S Ratio vs. Bed Height at $90 \%$ S. R., 1580 F Bed Temp.

Tidd PFBC Demonstration Plant

Ca/S Ratio vs. Bed Height at $90 \%$ SR, $1580 \mathrm{~F}$ Bed Temperature MM Pittsburgh \#8 vs. Consol MV Pittsburgh \#8 Coal; PRG Dolomite

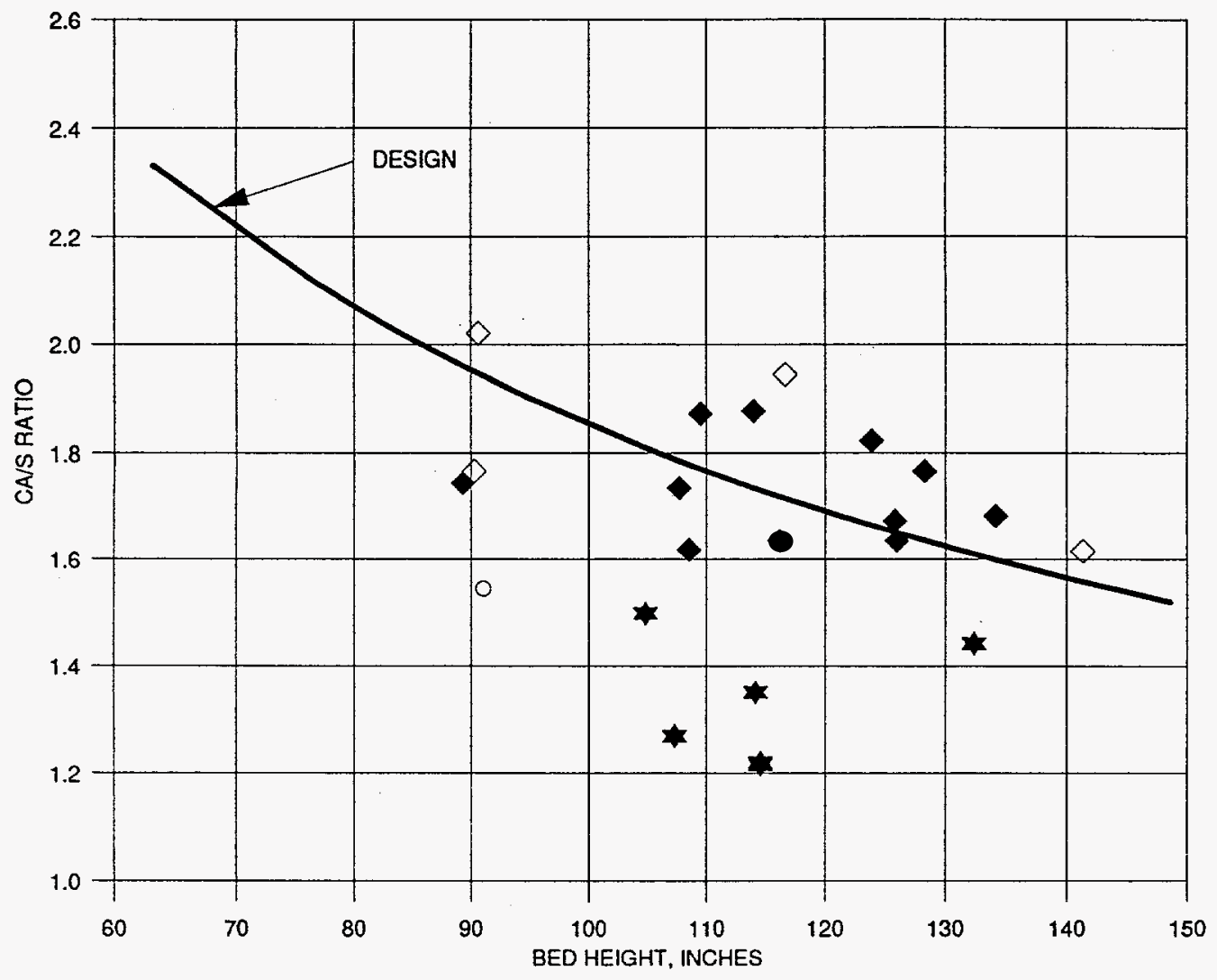

\begin{tabular}{|cccc|}
\hline MM Pittsburgh \#8 Coal & MM Pittsburgh \#8 Coal & Consol MV Pitts \#8 & Consol MV Pitts \#8 \\
PRG \#12-mesh Site & PRG \#12-mesh Designer & PRG \#12-mesh Site & PRG \#12×60-mesh Site \\
& $\downarrow$ & $\diamond$ & 0
\end{tabular}

4yr-Consol MV 7-APR-95

Tidd PFBC Demonstration Project

DOE Instrument DE-FC21-87 MC24132.000
Technical Progress Report

First Quarter CY 1995 
Figure 3. Cal S Ratio vs. Bed Height at $90 \%$ S. R., 1580F Bed Temp.

\section{Tidd PFBC Demonstration Plant}

$\mathrm{Ca} / \mathrm{S}$ Ratio vs. Bed Height at $90 \%$ SR, $1580 \mathrm{~F}$ Bed Temperature MM Pittsburgh \#8 vs. Minnehaha Coal; PRG and Mulzer Dolomite

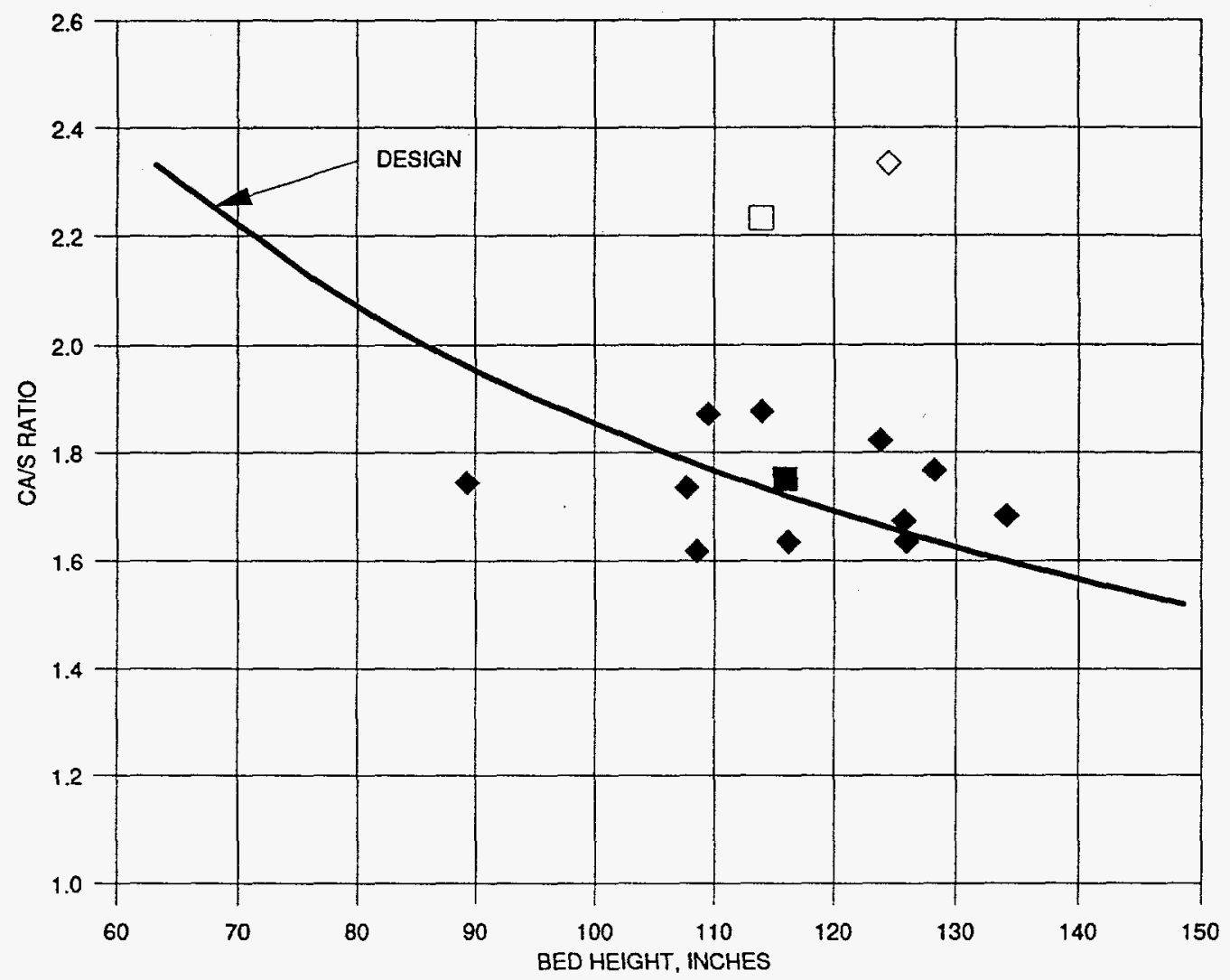

\begin{tabular}{|cccc|}
\hline MM Pittsburgh \#8 Coal & MM Pittsburgh \#8 Coal & Minnehaha Coal & Minnehaha Coal \\
PRG \#12-mesh Site & Mulzer \#12-mesh Site & PRG \#12-mesh Site & Mulzer \#12-mesh Site \\
& & $\diamond$ & $\square$
\end{tabular}

4yr-Minnehaha 7-APR-95

Tidd PFBC Demonstration Project DOE Instrument DE-FC21-87 MC24132.000 


\section{N. OPERATIONS}

The following is a summary of accumulated operating data for the period January 1,1995 through March 31, 1995.

Steam Turbine Generation $.47,267 \mathrm{MWH}$

Gas Turbine Generation. $10,426 \mathrm{MWH}$

Total Gross Generation. $57,693 \mathrm{MWH}$

Peak Generation for 1 Hour $.74 \mathrm{MWH}$

Total Oil Fire Operating Time 50.127 Hours

Total Coal Fire Operating Time 718.06 Hours

Total Coal Injected 27,866 Tons

Total Sorbent Injected $3,455.5 \mathrm{KLB}$

The unit was operated for a total of 1270.06 hours (including gas turbine warming). There were a total of 7 gas turbine starts, 9 bed preheater starts, and 9 operating periods with coal fire. The peak gross output of $74 \mathrm{MWH}$ was for the time period of $2200-2300$ on February 21, 1995, and again for the time period of $0400-0600$ on February 22, 1995.

The HGCU system was in service from January 13 through the end of the period.

1. The unit was in service at the beginning of the period as a continuation of TD-SU-94-12-02.

At the beginning of the period, the unit was operating at a bed level of $115^{\prime \prime}$ and a bed temperature of $1540^{\circ} \mathrm{F}$.

On Monday, January 2, 1995, the fuel preparation system Polysius crusher movable roll gear box failed. Due to the inability to prep coal, the combustor was tripped at 1057 hours on January 2,1995 . The bed material was cooled with the gas turbine; the gas turbine was removed from service at 2044 hours. The combustor was further cooled and released to maintenance for outage work.

2. Start-Up TD-SU-95-01-01. January 12,1995 - January 13, 1995

The combustor was released by the maintenance department at 1412 hours on January 12 , 1995.

The gas turbine was rolled at 0341 hours on January 13, 1995, and paralleled at 0406 hours. Air flow was established through the combustor at 0414 hours.

Oil fire was established at 0805 hours; the steam turbine was paralleled at 1253 hours. A coal fire was established at 1324 hours at a bed temperature of $1050^{\circ} \mathrm{F}$.

Sorbent injection was initiated at 1415 hours.

At approximately 1200 hours on January 13,1995 , \#16 cyclone began exhibiting signs of being plugged. As a result of this, the combustor was tripped at 1747 hours. The gas turbine was tripped at 1931 hours and after further cooling the unit was released to maintenance for outage work.

Tidd PFBC Demonstration Project

DOE Instrument DE-FC21-87 MC24132.000
Technical Progress Report

First Quarter CY 1995 
The combustor was released by the maintenance department at 203 hours on January 17. 1995.

The gas turbine was rolled on January 18, 1995 at 0523 hours. At 0541 hours, the gas turbine was paralleled and air flow was established at 0547 hours.

An oil fire was established at 1124 hours. The steam turbine was placed in parallel at 1518 hours.

A coal fire was established at 1553 hours at $1050^{\circ} \mathrm{F}$ bed temperature.

At 0839 hours on January 19, 1995 a gas turbine trip was experienced due to HCV-T122 (bypass intercept valve) going closed.

The bed was inerted with N2 and gas recirculation utilized to cool the bed.

Investigation into HCV-T122 revealed a small piece of O-ring material lodged in the orifice in the hydraulic circuit.

4. Start-Up TD-SU-95-02-02 January $20-21,1995$

The combustor was released by the maintenance department at 0613 hours on January 20 , 1995.

On Friday, January 20,1995 , the gas turbine was rolled at 1125 hours. At 1157 hours, the gas turbine was placed in parallel, and at 1225 hours air flow was established.

An oil fire was established at 1247 hours on January 20,1995 . The steam turbine was rolled at 1533 hours and placed in parallel at 1607 hours.

After gas turbine roll, bed temperatures were very unusual. Following oil fire, these bed thermocouples remained low, but did respond some. The bed had the appearance of poor fluidization.

A coal fire was established at 1735 hours, once again at $1050^{\circ} \mathrm{F}$ bed temperature.

The bed continued to have low temperature spots. Eventually, several evaporator tubes came into alarm while still below once through. It was decided to trip the unit and inspect the bed and sparge ducts. The combustor was tripped at 0044 hours, January 21, 1995. The gas turbine was taken off at 0618 hours on January $21,1995$.

5. Start-Up TD-SU-95-03-01 January 25 - February 2, 1995

The combustor was released by the Maintenance Department at 2306 hours on January 25 , 1995.

On Thursday, January 26, 1995, the gas turbine was rolled at 1257 hours. At 1327 hours,

Tidd PFBC Demonstration Project

DOE Instrument DE-FC21-87 MC24132.000
12

Technical Progress Report

First Quarter CY 1995 
the gas turbine was placed in parallel, and at 1336 hours air flow was established.

An oil fire was established at 1815 hours on January 26, 1995. The steam turbine was rolled at 2222 hours and placed in parallel at 2323 hours.

At 0058 hours, January 27, 1995, coal was lit. Once through occurred at 0652 hours on January 27, 1995. The bed was matured and on Monday, January 30,1995 , the bed level was increased to $125^{\prime \prime}$ and bed temperature raised from $1540^{\circ} \mathrm{F}$ to $1580^{\circ} \mathrm{F}$. Bed temperature distribution was excellent and the evaporator tube profile was nearly flat.

Several unusual excursions took place on the HGCU system on February 1, 1995. Tube sheet differential, ash temperatures, and gas turbine vibration were affected.

Early the morning of February 2, 1995, a blind flange in HGCU system, located on the backup cyclone outlet, was found to be hot, necessitating the removal of the unit from service. The combustor was tripped at 0205 hours on February 2, 1995. The gas turbine was removed from service at 1024 hours on February 2, 1995.

6. Start-Up TD-SU-95-04-01 February 7-9, 1995

The combustor was released by the Maintenance Department at 2300 hours on February 7, 1995.

On Wednesday, February 8, 1995, the gas turbine was rolled at 1043 hours. At 1115 hours, the gas turbine was placed in parallel, and at 1122 hours air flow was established.

An oil fire was established at 1850 hours on February 8,1995 . The steam turbine was rolled at 2308 hours and placed in parallel at 0014 hours on February 9, 1995.

At 0030 hours, February 9,1995 , coal was lit. Once through occurred at 0542 hours on February 9, 1995.

An instrument line on the economizer froze and broke. This resulted in a combustor trip at 1509 hours on February 9, 1995 due to high S.S.H. temperatures. The unit was readied for a hot re-start.

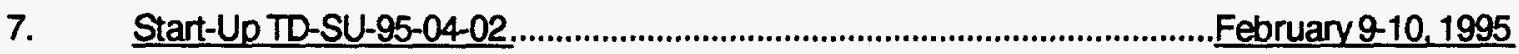

The unit was hot re-started following isolation of the economizer instrument and taking the bed up into 274 vessels.

An oil fire was established at 2326 hours on February 9,1995 . The steam turbine was rolled at 0255 hours on February 10, 1995 and placed in parallel at 0329 hours.

At 0408 hours, February 10, 1995, coal was lit. Once through occurred at 1018 hours on February 10, 1995.

The combustor was tripped at 1834 hours on February 10, 1995 due to a gasket failure on the line going to the HGCU surge hopper.

Tidd PFBC Demonstration Project

DOE Instrument DE-FC21-87 MC24132.000
Technical Progress Report

First Quarter CY 1995 
The unit was hot re-started following the repair of the gasket leak in the line going to the HGCU surge hopper.

On February 11, 1995, oil fire was established at 0454 hours, steam turbine was rolled at 0844 hours and paralleled at 0915 hours, coal fire was lit at 0926 hours, and once through occurred at 1222 hours.

The unit was brought up to 128 inches bed height. Steam flow reached $440,000 \mathrm{lb} / \mathrm{hr}$ and load went to $70.1 \mathrm{MW}$. The alternate ash line and emergency ash line in the HGCU system were plugged by 2 pieces of broken candle. Ash backed up and the water screw cooler tripped. The lockhopper was not able to remove ash fast enough and the ash level came up in the APF. The combustor was manually tripped at 1751 hours on February 12, 1995.

While trying to unplug the alternate ash line, the isolation valve stuck open. The valve handle was broken while trying to get the valve closed, necessitating a gas turbine trip at 0028 hours on February 13, 1995.

9. Start-Up TD-SU-95-05-01 February 13-16, 1995

The unit was hot re-started following a shutdown due to a high ash level in the HGCU APF.

The gas turbine was rolled at 0548 hours on February 13, 1995, paralleled at 0606 hours, and air flow established at 0647 hours.

On February 13, 1995, an oil fire was established at 0814 hours, steam turbine was rolled at 1100 hours and paralleled at 1136 hours, coal fire was lit at 1143 hours, and once through occurred at 1607 hours.

The unit was brought up to $112^{\prime \prime}$ bed level, at which time several hot spots appeared on the APF. Leak Repair, Inc. spent a day pumping Fibertrax to bring the temperatures down.

On February 16, 1995, problems developed with the fuel preparation system. The coal crusher was not able to properly crush the coal and the paste fines were low. All pump DP's increased. At 1243 hours, on February 16, 1995. it became necessary to trip the combustor due to both \#2 and \#3 paste pumps not pumping.

10. Start-UpTD-SU-95-06-01 February 16-March 8, 1995

The unit was warm re-started following a shutdown due to poor paste quality.

The fuel nozzles were cleaned. The coal in the bunkers was emptied out. It was determined the main coal pile was getting down to some old coal and possibly some $6 \mathrm{~A}$ coal. A switch was made to the south pile, which crushed fine.

The gas turbine was rolled at 0848 hours on February 18, 1995, paralleled at 0924 hours, and air flow established at 1003 hours.

On February 18,1995 , an oil fire was established at 1533 hours, steam turbine was rolled

Tidd PFBC Demonstration Project DOE Instrument DE-FC21-87 MC24132.000
Technical Progress Report

First Quarter CY 1995 
at 1805 hours and paralleled at 1850 hours, coal fire was lit at 1929 hours, and once through occurred at 2230 hours.

The unit was brought up to $133^{\prime \prime}$ at $1580^{\circ} \mathrm{F}$ bed temperature on delivered \#12 Plum Run dolomite. Four tests were run in the week of February 23 to March 1, 1995, and four additional tests were conducted the week of March 1 to March 8, 1995.

On March 8, 1995, problems again developed with the fuel preparation system. The coal crusher was not able to properly crush the coal and the paste fines were low. All pump DP's increased. At 1440 hours, on March 8, 1995, it became necessary to trip the combustor due to two paste pumps not pumping. Extremely wet coal was the cause of the crushing difficulty.

11. Start-Up TD-SU-95-07-01 March 13-30, 1995

The unit was released from a mini gas side clearance at 2050 hours, on March 13,1995 following a shutdown due to poor paste quality.

The fuel nozzles were cleaned. The coal in the bunkers was emptied out. It was determined that the quality of coal which was being received on a daily basis was suspect due to its high moisture content. The rolls of the crusher were dressed and the minimum gap was reset. This coupled with a more consistent coal supply allowed the preparation system to perform at a rate that could support unit operation.

The gas turbine was rolled at 0531 hours on March 14, 1995, and paralleled at 0552 hours, and air flow established at 0603 hours.

On March 14, 1995, at 1059 hours oil fire was established. The steam turbine was rolled at 1355 hours and paralleled at 1506 hours, on March 14, 1995. Coal fire was established at 1715 hours on March 14, 1995, followed by once through boiler operation being established at 2041 hours.

The unit was brought up to $115^{\prime \prime}$ bed level and $1580^{\circ} \mathrm{F}$ bed temperature on site prepared Plum Run dolomite. Two tests were run the week of March 13, 1995 to March 20, 1995. The week of March 20, 1995, the sorbent preparation system was set up in scalping/ de dusting mode and the bed level was reduced to $90^{\prime \prime}$ in order to complete two more tests. The week of March 27, 1995, one test was completed with the bed level at 115", utilizing site prepared National Lime limestone.

The operation of the unit through out the period was characterized by excessive leakage in the external primary ash cooler. By the time the unit was removed from service, the closed cycle cooling expansion tank level was being topped off 25 times every shift. The combustor was tripped for the final time at 0827 hours, on March 30, 1995. 
V. MAINTENANCE

1. Outage TD-OT-95-01-01. January $2-12,1995$

Polysius crusher movable roll gear box bearings failed causing the unit to be removed from service. Both gear boxes on the movable and stationary rolls were replaced.

Restored HGCU system for service, include APF vessel (with new candle filters), expansion joins, dirty gas piping, etc. Replaced the original backup cyclone ash line with new piping having longer radius bends. Backpulse compressor fourth stage discharge valve, oil seals and gaskets were replaced. APF surge hopper valves HCV-J926, -927, and -928 were changed and linkage was adjusted for limit switches.

Video boroscoped LPT inner guide vane ring which indicated some wear. Visual inspections were also conducted. LPT disc temperatures were high, requiring us to increase openings on V-12 and V-13 orifices to $18 \mathrm{~mm}$ and $28 \mathrm{~mm}$, respectively. A bypass was also installed around $V-13$ orifice. This bypass has a $10.5 \mathrm{~mm}$ orifice installed. Inspected and repaired a leak in the gas turbine intercooler.

Sorbent booster compressor inlet guide vane assembly was bound up, therefore it was disassembled and cleaned for smoother operation.

Replace number 7 cyclone $\mathrm{O} 2$ analyzer tubing completely. Replaced number 3 cyclone $\mathrm{O} 2$ analyzer piping at cyclone duct to first Swagelok fitting.

Repaired leaks on primary ash piping inside internal ash coolers.

2. Outage TD-OT-95-02-01 January 13 - January 17, 1995

The unit was taken out of service because number 16 cyclone was plugged, thereby preventing ash flow.

Inspected screw cooler, outlet pipe, surge and lockhoppers. Recovered several small pieces of silicone carbide candle. Inspected and cleaned ash from alternate ash line. Removed small piece of candle which plugged the orifice.

3. Outage TD-OT-95-03-01 January $19-$ January 20, 1995

The gas turbine tripped due to a piece of O-ring which was blocking control fluid flow to bypass valve T-122. This restriction caused the valve to close. Repairs were made by the Performance Department.

4. Outage TD-OT-95-04-01 January 21. January 25, 1995

The bed was not able to fluidize, causing us to bring the unit out of service. Inspected central duct and sparge ducts and found excessive build up of ash; vacuumed out same. Sand-blast cleaned sparge nozzles. Inspected bed cooling air tubes and found bed material, which was vacuumed out.

Tidd PFBC Demonstration Project DOE Instrument DE-FC21-87 MC24132.000
Technical Progress Report

First Quarter CY 1995 
Removed unit from service due to elevated temperatures $\left(1400^{\circ} \mathrm{F}\right)$ on the backup cyclone (BUC) outlet tee blind flange. Removal of the blind flange revealed missing insulation from behind a holding plate which failed. Fragments of these plates were found in the gas turbine LP exhaust duct and 3 plates were found intact at the inlet guide vanes of the HP turbine. A revised design of insulating the blind flanges was utilized.

6. Outage TD-OT-95-06-01 February 16-February 18, 1995

Due to bad coal paste, number 3 fuel nozzle plugged and shortly after, number 2 nozzle plugged. Because of this and problems crushing coal, the unit was taken out of service. All nozzles were disassembled, from outside of the combustor, cleaned and restored. All coal bunkers, paste tanks and the truck hopper were emptied of coal which created crushing and pluggage problems. Polysius crusher rolls were adjusted more closely on each side by $4 \mathrm{~mm}$ to $4 \mathrm{~mm}$ on the left side and $5 \mathrm{~mm}$ on the right (north).

Inspected the advanced particle filter (APF) for broken candle pieces. Removed pieces of candle from the ash transport piping below the APF lockhopper. Unplugged ash from the alternate ash line. Installed a screen arrangement in the alternate ash line to prevent future pluggage. Unplugged ash from the emergency ash line purge air supply. 


\section{MANPOWER REPORT}

As of March 31, 1995, AEPSC actual work-hours for the Phase III accounted for $48.3 \%$ of the total budget of 135,098. Figure 4 represents the budget versus actual work-hours for this phase. For the reporting period, a total of $3,060.2$ hours were charged to the project by AEPSC personnel.

FIGURE 4

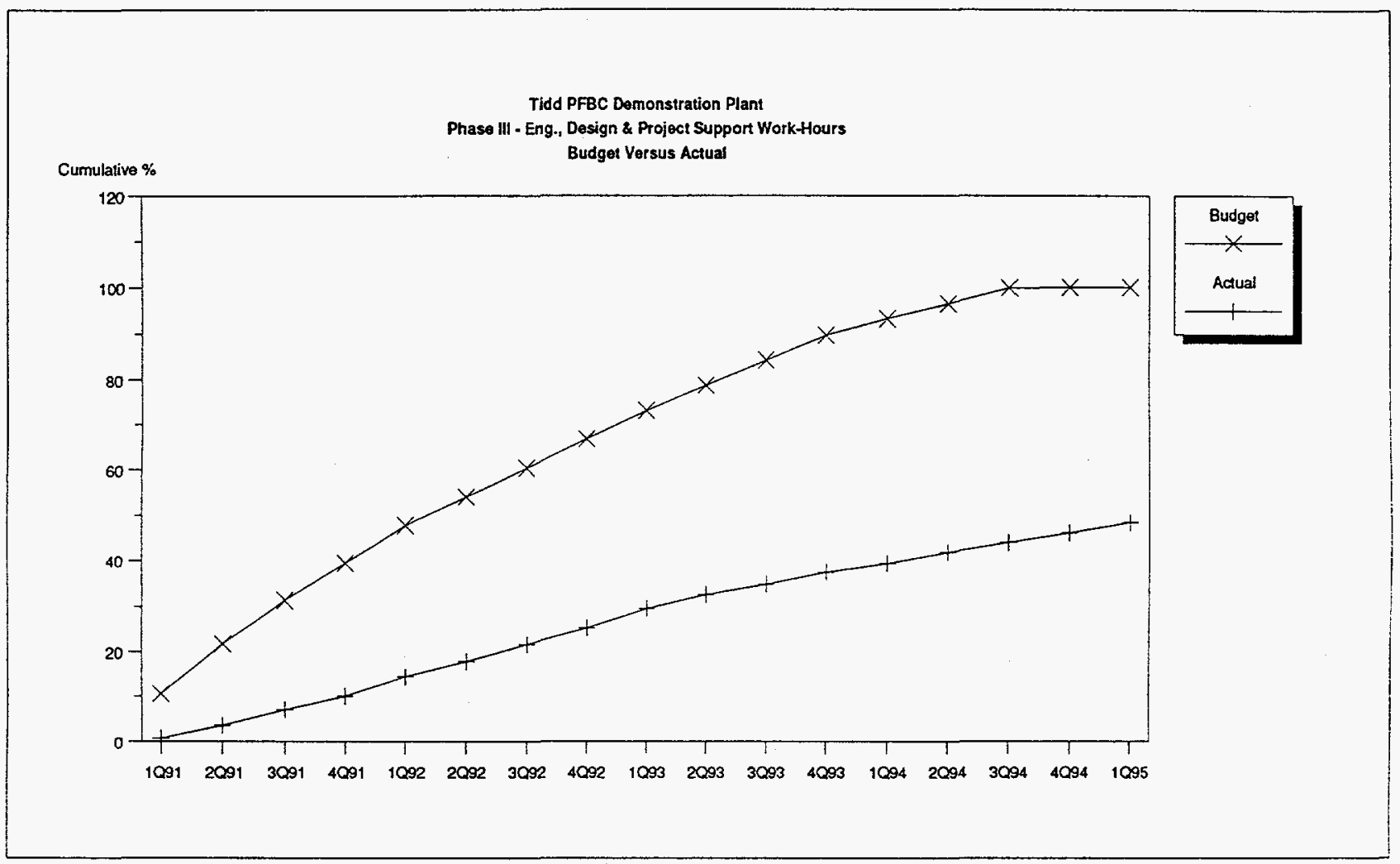

\begin{tabular}{|c|c|c|c|c|c|c|c|c|c|c|c|c|c|c|c|c|c|}
\hline & 1091 & 2091 & 3094 & $4 \mathrm{CQ91}$ & 1092 & 2092 & 3092 & 4092 & 1093 & 2093 & 3093 & $4 Q 93$ & 1094 & 2094 & 3094 & 4094 & 1095 \\
\hline Actual & 0.7 & 3.6 & 7.1 & 10.1 & 14.4 & 17.8 & 21.6 & 25.2 & 29.5 & 32.5 & 34.8 & 37.4 & 39.3 & 41.8 & 44.0 & 46.1 & 48.3 \\
\hline
\end{tabular}

Tidd PFBC Demonstration Project

DOE Instrument DE-FC21-87 MC24132.000
Technical Progress Report

First Quarter CY 1995 


\section{COST DATA}

1. Project Cost Status

The actual cost shared expenditures during the First Quarter 1995 were $\$ 694,893$. As of March 31, 1995, the cumulative cost shared expenditures for Phase I, II, and III were $\$ 179,688,644$.

Figure 5 depicts the cumulative expenditure forecast for the project from Calendar Year (CY) 1986 to $\mathrm{CY}$ 1995. This cash flow curve represents the entire project, all three phases, including expenditures that are not cost shared with DOE.

FIGURE 5

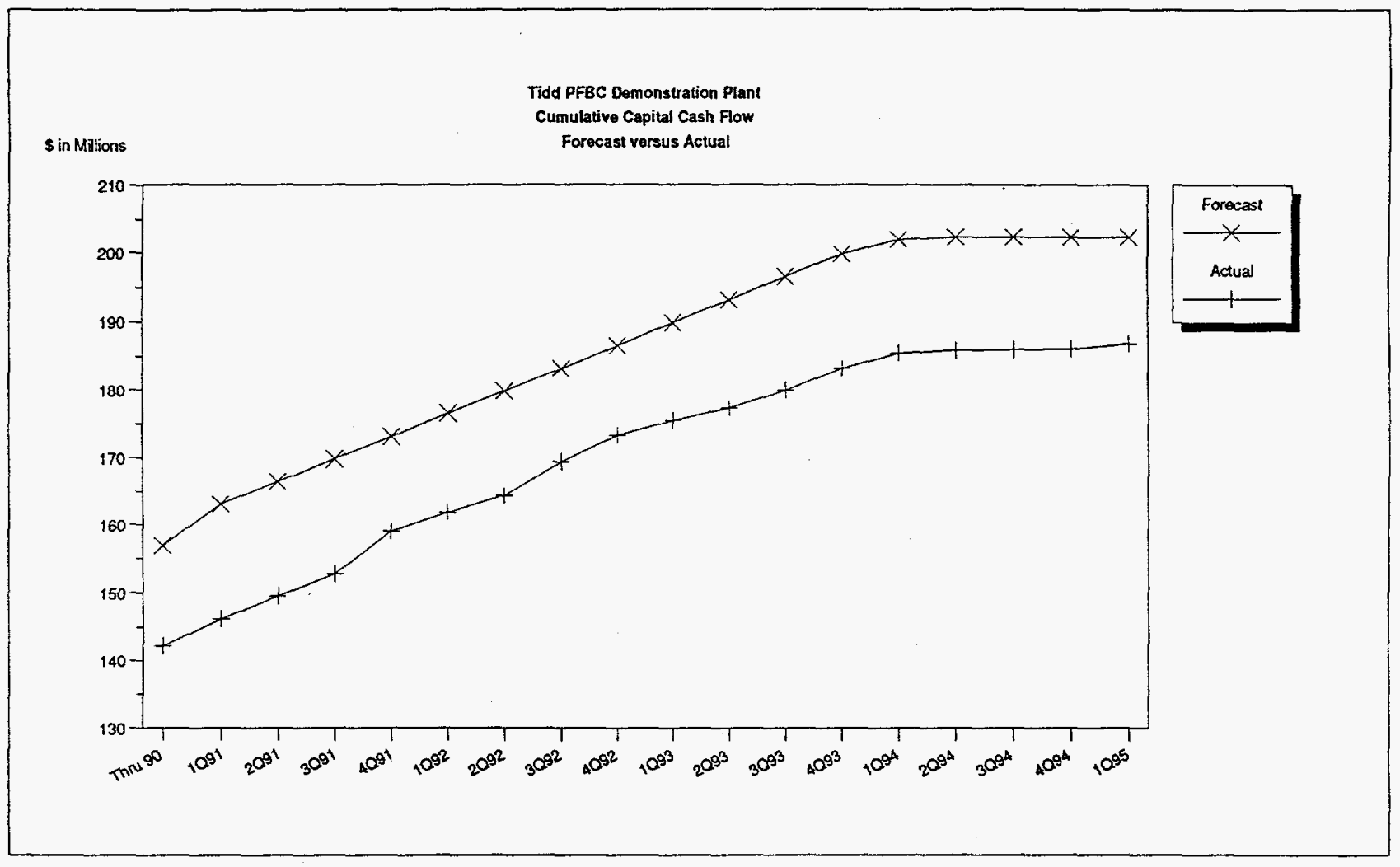

\begin{tabular}{|c|c|c|c|c|c|c|c|c|c|c|c|c|c|c|c|c|c|c|}
\hline & (in Millions & & & & & & & & & & & & & & & & & \\
\hline & Thru 90 & 1091 & 2091 & 3091 & 4091 & 1092 & 2092 & $3 \mathrm{Q92}$ & 4092 & 1093 & 2093 & 3093 & 4093 & 1094 & 2094 & 3094 & 4094 & 1095 \\
\hline Forocast & 156.9 & 163.1 & 166.5 & 169.8 & 173.1 & 176.5 & 179.8 & 183.1 & 186.5 & 189.8 & 193.1 & 196.5 & 199.8 & 202.0 & 202.4 & 202.4 & 202.4 & 202.4 \\
\hline Actual & 142.2 & 146.2 & 149.6 & 152.7 & 159.0 & 161.8 & 164.4 & 169.4 & 173.3 & 175.4 & 177.2 & 179.9 & 183.2 & 185.5 & 185.9 & 186.0 & 186.1 & 186.8 \\
\hline
\end{tabular}

Tidd PFBC Demonstration

DOE Instrument DE-FC21-87 MC 24132.000
Technical Progress Report First Quarter CY 1995 
Figure 6 is a projection of the quarterly expenditures for all participants. It also identifies the actual quarterly expenditures through the First Quarter 1995.

FIGURE 6

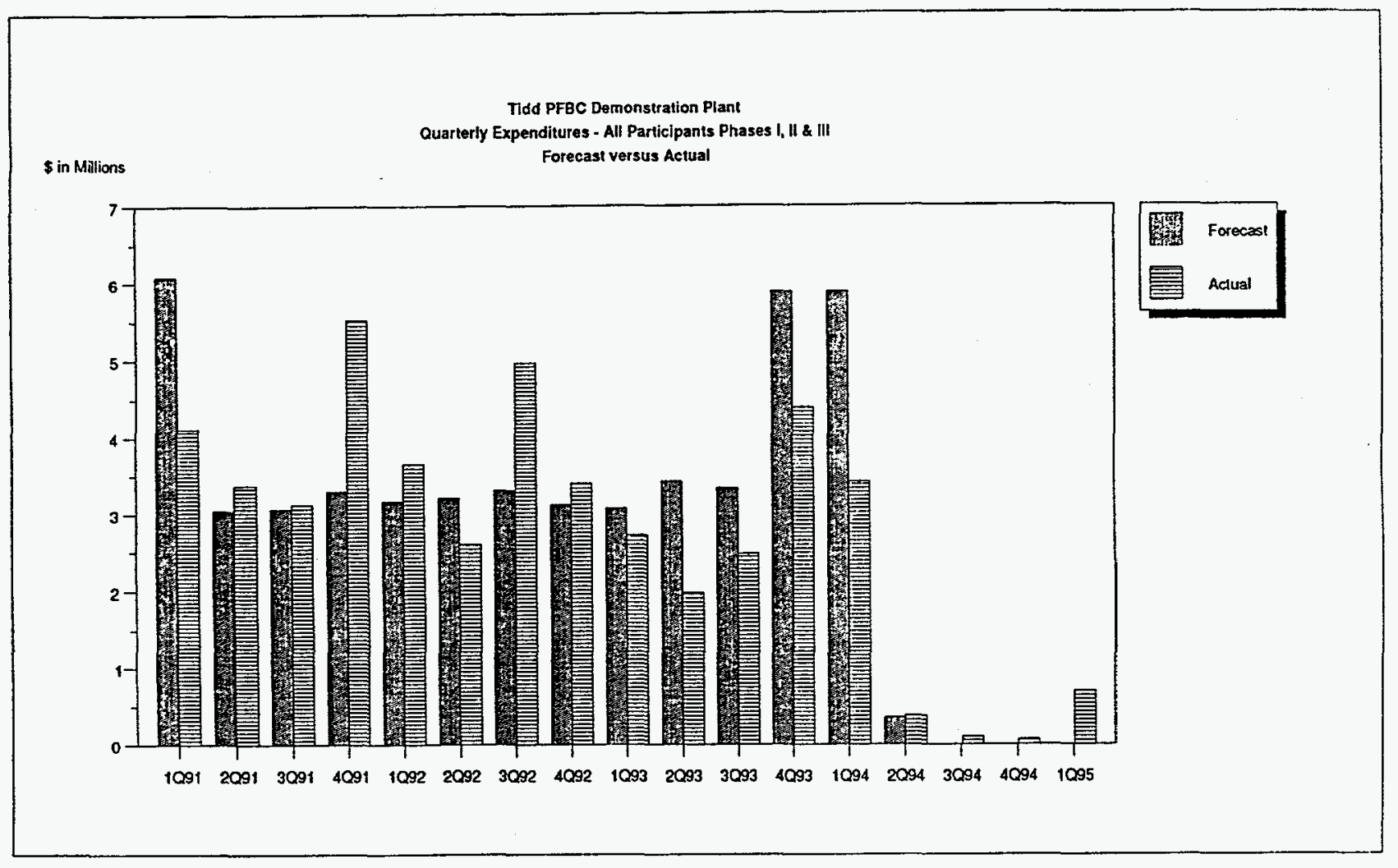

\begin{tabular}{|c|c|c|c|c|c|c|c|c|c|c|c|c|c|c|c|c|c|c|c|}
\hline & (in Million & & & & & & & & & & & & & & & & & & \\
\hline & Thru 90 & 1091 & 2091 & 3091 & $4 Q 91$ & 9092 & 2092 & 3092 & 4092 & 1093 & 2093 & 3093 & 4093 & 1094 & 2094 & 3094 & $4 Q 94$ & 1095 & To-daio \\
\hline Forecast & 143.289 & 6.082 & 3.044 & 3.063 & 3.298 & 3.161 & 3.212 & 3.311 & 3.116 & 3.072 & 3.427 & 3.334 & 5.889 & 5.888 & 0.354 & 0.000 & 0.000 & 0.000 & 193. \\
\hline Actual & 132.688 & 4.107 & 3.373 & 3.121 & 5.521 & 3.659 & 2603 & 4.967 & 3.402 & 2721 & 1.979 & 2.478 & 4.397 & 3.423 & 0.384 & 0.103 & 0.067 & 0.696 & i79. \\
\hline
\end{tabular}


The following table summarizes the project expenditures as of March 31, 1995, of all participants:

Total Expended

as of

Phase I

Design \&

Permitting

Phase II

Construction \&

Start-up

Phase III

Operation, Data

Collection,

Reporting \&

Disposition

Total:

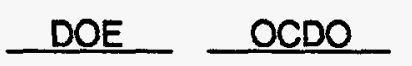

$\$ 8,469,449 \$ 5,000,000$

$\$ 49,095,184 \$ 5,000,000$

$\$ 68,128,704 \quad \$ 122,223,888$
$\$ 29,725,573 \$ 35,925,573$

$\$ 63,764,633 \quad \$ 10,000,000$

$\$ 105,924,011 \$ \$ 179,688,644$ 
Figure 7 is the Phase III DOE quarterly actual and projected expenditures.

FIGURE 7

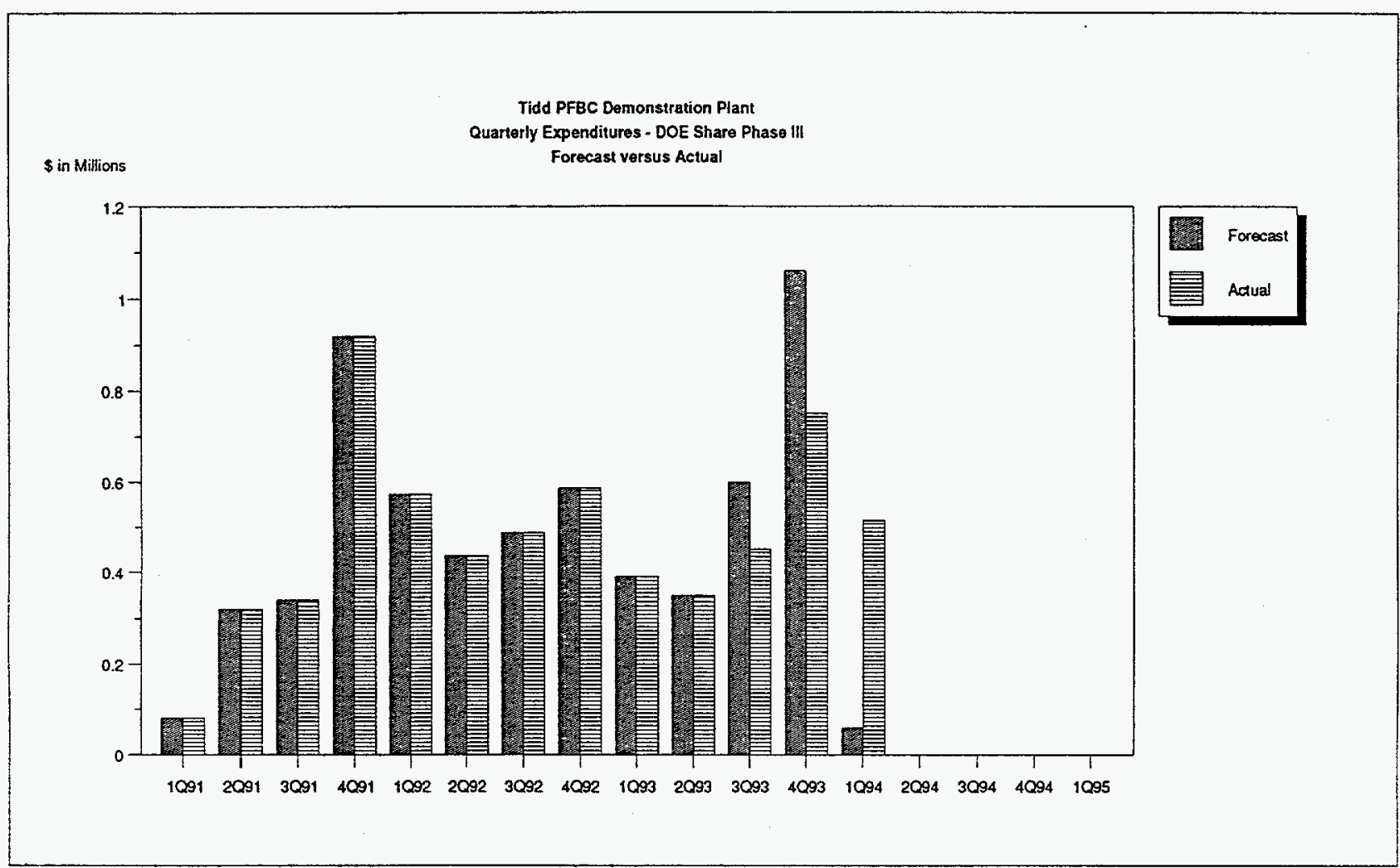

\begin{tabular}{|c|c|c|c|c|c|c|c|c|c|c|c|c|c|c|c|c|c|c|}
\hline & (in Million & & & & & & & & & & & & & & & & & \\
\hline & 1091 & 2091 & 3091 & 4091 & 1092 & 2092 & 3092 & 4092 & 1093 & 2093 & 3093 & 4093 & $1 \mathrm{Q94}$ & $2 \mathrm{Q} 94$ & 3094 & 4094 & 1095 & TO-DATE \\
\hline Forecast & 0.080 & 0.320 & 0.339 & 0.918 & 0.573 & 0.437 & 0.488 & 0.587 & 0.391 & 0.348 & 0.600 & 1.060 & 0.059 & 0.000 & 0.000 & 0.000 & 0.000 & 6.200 \\
\hline Actual & 0.080 & 0.320 & 0.339 & 0.918 & 0.573 & 0.437 & 0.488 & 0.587 & 0.391 & 0.348 & 0.451 & 0.752 & 0.515 & 0.000 & 0.000 & 0.000 & 0.000 & 6.200 \\
\hline
\end{tabular}

Tidd PFBC Demonstration

DOE Instrument DE-FC21-87 MC 24132.000 
The following represents the financial status of the Tidd PFBC Demonstration Project - Phase III 4th year, as of March 31, 1995.

\section{Expenditures}

Operations (Est. $\$ 12,457,000)$

$\$ 11,265,101^{\circ}$

Funding Source

- USDOE Share of Cost Growth

- USDOE Cost Sharing

$(\$ 3,564,633)$

$(\$ 3,192,360)$

$(\$ 2,600,000)$

- OCDO Cash Contribution

$(\$ 2,300,007)$

- OPCO Coal Contribution

(\$ 400,000$)$

- ABBC Contribution

(\$400,000)

$\$ 3,564,633$

$2,465,149$

$2,340,000$

$2,288,782$

200,000

- B\&W Contribution

406.537

Total Funding To-Date

$\$ 11,265,101$

Remaining Portion of Expenditures to be Recovered

$\$(0)$

\section{Contracts Awarded During First Quarter 1995}

No major contractual commitments were issued during this reporting period.

*Expenditures do not Include the March 1995 Unvouchered Charges totaling $\$ 486,861$ and provisions for estimated future costs totaling $\$ 887,000$. 
Figure 8 is the 4th Year Operations Quarterly Actual and Projected DOE Share of Expenditures.

FIGURE 8

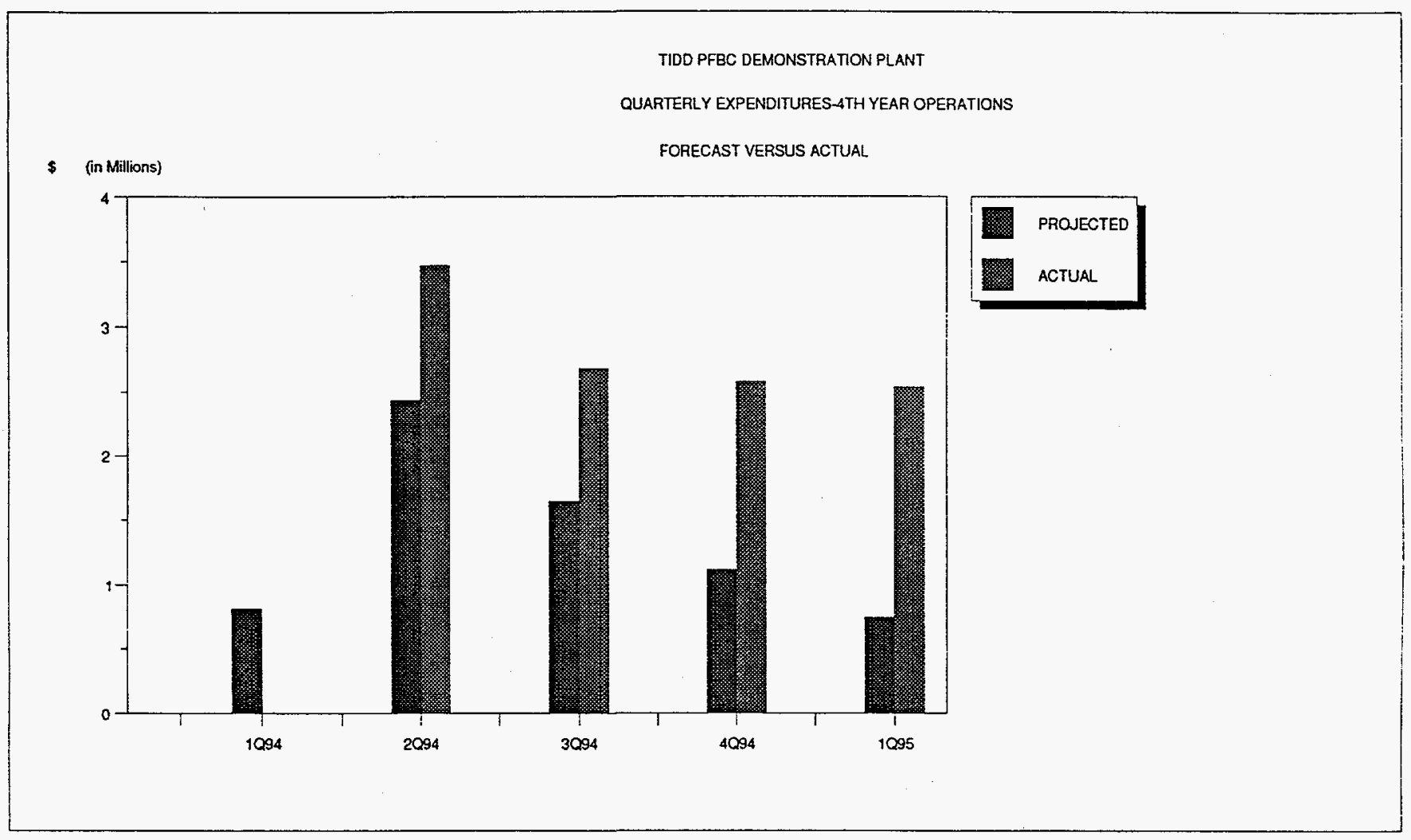

\begin{tabular}{|c|c|c|c|c|c|c|c|c|}
\hline & 1094 & & 2094 & & 3094 & $4 Q 94$ & & 1095 \\
\hline PROJECTE & 813000.0 & $\because$ & 2439000.0 & $*$ & 1641000.0 & 1117000.0 & $*$ & 748000.0 \\
\hline ACTUAL & 0.0 & \pm 1 & 3469363.0 & 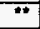 & $2679045.01=$ & 2577914.0 & $*$ & 2538779.0 \\
\hline
\end{tabular}

